\title{
IMPROVING STUDENTS' ABILITY TO READ NARRATIVE TEXT USING VIDEO THROUGH SQ3R (SURVEY, QUESTION, READ, RECITE, AND REVIEW) METHOD
}

\author{
Panji Alen Syahputra, Dewi Rochsantiningsih, Muh. Asrori \\ English Education Department \\ Teacher Training and Education Faculty \\ Sebelas Maret University of Surakarta
}

\begin{abstract}
This article discusses: (1) to what extent the use of videos and SQ3R method improves the students' ability in reading narrative text; and (2) to describe the class climate when videos and SQ3R method are implemented in the reading class. The qualitative data were obtained by observation, interview, and questionnaire. And they were analyzed through: get to know the data, focus the analysis, categorize information, identify patterns, connection within and between categories, and interpretation. While the quantitative data were obtained by using test and analyzed by using formulas. The research result shows that (1) the use of video through SQ3R method improves the students' reading skill; and (2) the use of video through SQ3R method leads the class climate of reading class better than the situation prior to the research implementation. They become more active, confident, and enthusiastic.
\end{abstract}

Keywords: Survey, Question, Read, Recite, Review (SQ3R), students' reading skill

\section{INTRODUCTION}

English as one of compulsory lessons which must be taught in SMA holds an important role in increasing the students' ability in using English language as one of means of communication. One of the skills which must be mastered by the students in Senior High School is reading. It is an important and interesting activity. Reading helps people to get information widely and it can increase knowledge without going anywhere.

The kind of long texts which are taught in the first grade of senior high school are recount, narrative, procedure, descriptive and news item. In the curriculum, reading is one of the competence standards conducted to the students. Reading must be mastered by them to comprehend the meaning of several texts.
Teaching reading is not easy, because it requires creativity and motivation to the students in order to create a good situation and condition when teaching and learning process are conducted. The students need the interesting technique to improve their reading comprehension.

Aebersold and Field (1997: 15) define that reading is something which people look at the text and assign to the written symbols in that text. In other words, we assume that reading activity is people's activity to read a text.

Reading is not the activity to read aloud but to comprehend the message and information in the text and it does not necessarily need to look everything in a given piece of text. The important things in reading are to comprehend the text in order to catch the information and message in the 
written text. Reading is very important to be given as a skill in English lesson and becomes the compulsory skill in English learning in the Senior High School curriculum.

Reading is one of the four skills in language learning. It is more than the activity of pronouncing printed material of written page. It involves various and complex activities.

Aebersold and Field (1997: 15) state that reading is what happens when people look at the text and assign meaning to the written symbols in that text. It means that reading is the activity where words are written on the paper but also looks for their meaning. Pang, et al. (2003: 6) define reading as a complex activity that involves both perception and thought. Reading consists of two related processes: word recognition and comprehension. Further, they explain that word recognition means the process of perceiving how written symbols correspond to one's spoken language. Then, comprehension refers to the process of making some words, sentences, and connected text. They also state that readers typically make use of background knowledge, vocabulary, grammatical knowledge, experience with text and other strategies to help them understand written text.

It can be summarized that reading is an activity related to written symbolic message that the reader must catch the message from the arranged words, sentences, and paragraphs.

Based on the research, the researcher finds some problems in reading comprehension. The problems come from the students and the teacher. The students have low reading ability. The indicators of low reading ability are: (a) the students have difficulty to get the main idea of the text, (b) the students have difficulty to get detail informations, (c) the students have difficulty to get the meaning of words from the text, (d) the students have difficulty to find the reference in the text, and (e) the students have difficulty to get the purpose of the text. The teacher has a difficulty in using a teaching method. It indicates that the students mostly do not understand what the teacher has explained, and sometimes the students feel bored with the conventional method.

The fact that the students lacked of reading skill was also supported by the findings of the pre test on the pre research which showed that the students' mean score in reading was 57.50. Meanwhile, the students' individual score ranged from 35 as the lowest one to 70 as the highest one. It means that all of the students had not reached the minimum requirement score yet, that is, 75 .

Besides, the fact also showed that the students' achievement in reading has not reached the standart (KKM). The mean score of each indicator of reading was still lower than the KKM. Most of the students admitted that they often felt bored when they had to read a text, especially a long and uninteresting topic text.

In this research, the researcher uses video as the medium and SQ3R (Survey, Question, Read, Recite, Review) as a method in teaching reading narrative texts. Smaldino, et al. (2005: 283) define video as electronic storage of moving images (videotapes, DVD, etc.). He adds that any electronic media format that employs "moving picture" to present a message can be referred to as video. Video takes huge contribution in teaching and learning activity as a teaching media. Harmer (2008: 290) states that video can enhance simulations, not only because it can provide feedback when students can watch themselves and evaluate their performance, 
but also because the presence of a video helps to make students feel more realistic.

The SQ3R method has been known as the essential study method for textbook reading for the last 40 years. The SQ3R Method requires students to survey, question, read, recite and review textbook material. This method allows students to use their memories to their full potential by creating a visual and auditory memory of the text as well as using repetition of the material as sort of a rote style of memory.

SQ3R (Survey, Question, Read, Recite, and Review) method is developed by Robinson (1946). The steps in the SQ3R method, and a description of each are given below:

a. Survey, the students review the text to gain initial meaning. The students survey the text by reading and thinking about the text title, the introductory paragraph, informations, the concluding paragraph, and the end of chapter questions. The student should have a general understanding of the text.

b. Question, the students begin to generate questions about their reading from previewing it. The students ask questions from the informations in the text and restate it in the form of questions.

c. Read, the students must re-read the text immediately to find the answer to the question developed in the previous step. As students read, they need to look for answers to the questions they formulated during their preview of the text.

d. Recite, the students must recite the information obtained in step 3 by restating the answer in their own words and then writing the response. As students move through the text they should recite or rehearse the answers to their questions and make notes about their answer for later studying. e. Review, the students should review the text to answer lingering questions and recite the questions they previously answered. The students must review the above information for 5 minutes and attempts to recall the main points of the chapter and the supporting details.

This article aims at discussing: (1) to what extent the use of videos and SQ3R method improve the students' ability in reading narrative text; and (2) to describe the class climate when videos and SQ3R method are implemented in the reading class.

Finally the researcher assumed that the use of video through SQ3R method in reading class could improve reading skill and lead the class climate better on class XB of one of MA in Sragen.

\section{RESEARCH METHODS}

The research method used in this study is classroom action research. Action aims to contribute both to the practical concerns of people in an immediate problematic situation and to the goals of social science by joint collaboration within a mutually acceptable ethical framework. (Rapoport: 1970 in Burns, 1999: 29).

During the research, the writer uses action research method. Action research is diciplined inquiry (research) which seeks focused efforts to improve the quality of people's organizational, community and family lives. (Stringer: 1996 in Mulyasa, 2009: 33).

The research is conducted in two cycles. This action research consists of planning, action, observation, and reflection. There are two types of data: The qualitative data were obtained by observation, interview, and questionnaire. And they were analyzed through: get to know the data, focus the analysis, categorize information, identify patterns, connection within and 
between categories, and interpretation. While the quantitative data were obtained by using test and analyzed by using formulas.

Burns (1999: 1) divides the characteristics of action research: 1) Action research is contextual, small scale and localized. It identifies and investigates problems within a specific situation, 2) it is evaluative and reflective as it aims to bring about change and improvement in practice, 3 ) it is participatory as it provides for collaborative investigation by teams of colleagues, practitioners and researchers, 4) Changes in practice are based on the collection of information or data which provides the impetus for changes.

Based on previous explanations, action research is in the form of cycles of activity. Action research is learning by doing in which a group of people are identifying a problem, doing something to solve it, observing how success their effort.

\section{RESEARCH FINDINGS AND DISCUSSIONS}

The research was carried out in two cycles through the following stages: 1), planning the action; 2) Implementing the action; 3) observing the action; 4) reflecting the action, 5) revising the plan.

In this research, the implementation was conducted in two cycles. The researcher planned four meetings in cycle 1 and three meetings in cycle 2 through planning, acting, observing, reflecting, and revising stages.

The pre-research was conducted before the implementation of the study. The purpose of the pre-research is to identify the students problems in reading text, the problems during teaching learning process, and students' reading skill. The pre-research covered three steps: 1). Interviewing the teacher and the students; 2). Observing the teaching learning process; and 3). Giving pre-test to the students.

Based on the result of pre-test, The highest score was 70 and the lowest score was 35 , the students' mean score was 57.50 and the KKM is 75 . The mean score was still lower than KKM. It can be concluded that the students' reading ability should be improved.

Based on the result of the post test score of cycle 1, the researcher could report that there was improvement on students' reading ability. The highest score improved from 70 in pre test into 85 in post test 1 . The lowest score improved from 35 in pre test into 60 . The mean score between pre test and post test improved from 58 into 69.

The most significant indicators of reading comprehension which improved are finding detail information and finding word meaning. Those indicators can be shown from the mean score of the indicator which improved such as: the ability of finding main idea increased from 63.75 up to 78.75 ; the ability of finding detail information increased from 61.25 up to 77.50 ; the ability of finding word meaning increased from 45 up to 61.25 ; the ability of identifying reference increased from 46 up to 65 ; the ability of identifying purpose of text did not increase at all from 70 up to 70 . Besides, the students' average scores improved from 57.5 (pre-test score) to 70, 5 (post-test 1).

At first, the students were not interested and active in reading class. During the first cycle of research was implemented, the students attitude was better, they looked enthusiastic, they also enjoyed the class, and paid to the lesson seriously. The intensity of making some noise was reduced since the use of videos as stimulus was played. It could be claimed that students reading skill and the class climate were improved in cycle 1. 
Based on the result of the post test score of cycle 2, the researcher could report that there was improvement on students reading. The highest score improved from 85 in post-test 1 into 95 in post-test 2 . The lowest score improved from 60 in post-test 1 into 65 in post-test 2 . The mean score between post-test 1 and post-test 2 improved from 70.50 into 78.75 .

In post-test 2, the most significant indicators of reading comprehension which improved is finding word meaning. It can be shown from the mean score of the indicator which improved such as: the ability of finding main idea increased from 78.75 up to 83.75 ; the ability of finding detail information did not show improvement; the ability of finding word meaning increased seriously. The students' improvement of reading skills can be seen in the table 1 .

The finding also shows that the students and teachers made reading class more active. Both teacher and students kept various interesting activities in the class. Students take part in all activities and keep focus in the lesson. The students enjoyed and were interested in the classroom situation. They have responsibility to their reading activity. So, they do not have more time to have a joke with the other. It can be said that the students were not noisy during the class activity

The use of video through SQ3R method can enhance the students' reading comprehension by implementing the steps of the method sequencely and properly. The

Table.1. The Improvement of Students' Reading Skills

\begin{tabular}{clccc}
\hline \multirow{2}{*}{ No } & \multicolumn{1}{c}{ Skills } & \multicolumn{3}{c}{ Mean score of each skills } \\
& & Pre-test & Post-Test 1 & Post-test 2 \\
\hline $\mathbf{1}$ & Finding main idea & 63.75 & 78.75 & 83.80 \\
$\mathbf{2}$ & Finding detail informations & 61.25 & 78.00 & 77.50 \\
$\mathbf{3}$ & Finding meaning of words & 45.00 & 61.25 & 76.30 \\
$\mathbf{4}$ & Identifying references & 47.50 & 65.00 & 75.00 \\
$\mathbf{5}$ & Identifying purpose of text & 70.00 & 70.00 & 82.50 \\
& Mean Score & 57.50 & 70.50 & 78.75 \\
\hline
\end{tabular}

from 61.25 up to 76.25 ; the ability of identifying reference increased from 65 up to 75 ; the ability of identifying purpose of text did not increase at all from 70 up to 7 increased from 70 up to 82.50 . Besides, the students' average scores improved from 70.50 (post-test 1 score) to 78.75 (post-test 2).

In cycle 2, the students already showed good progession. The result of pretest improved. During the second cycle of research was implemented, the students' attitude was better, they were more enthusiastic with the text given, they enjoyed the class, and paid to the lesson students must practice with enough guidance from the teacher and researcher. The focuses of the research involved five aspects of reading comprehension: inferring main idea, finding detail informations, understanding word meaning, identifying reference, and identifying purpose of text. The result shows that those aspects raise higher final achievement after the research.

The use of video led the class climate of reading class better than the situation prior to the research implementation. At first, the students were not active, it can be seen when they were given a text, they did not pay attention and when they are asked to do exercise, they 
cannot do it in right way. During the research implementation, Students understood the lesson, it could be seen that they were active to ask about the vocabularies that they did not understand. Stempleski, et al (1990: 3) claims that the introduction of a moving picture component as a language teaching aid is a crucial addition to the teacher's resources. It will help students through motivation and communication.

The final result shows that the mean of score of the reading comprehension test improved, so it can be concluded that the implementation of video through SQ3R method enhance students' reading comprehension and class climate.

\section{CONCLUSIONS AND SUGGESTIONS}

The findings of the results show the positive improvements in the students' reading skill and class climate. The enhancement of the students' reading skill is also supported by the result of the test scores. The mean score of pre-test was 57.50 and it improved into 70.50 in the post-test cycle 1 and 78.75 in the final post-test cycle 2. It proves that the use of video through SQ3R method in teaching reading can improve the students' reading skill. To improve the students' ability in reading, the teacher asked students to watch video and asked them to listen to the speaker while they watched the subtitle. It helped the students to understand the story in narrative text.

Referring to the research findings, the class got better in the beginning of the lesson. The improvements are indicated by students' motivation in learning that was increased; students listened to the researcher enthusiastically; students often asked for difficult words; and students involved in learning actively. Students did the presentation in the end of each cycle. They presented well toward to the material and the audience asked questions to the presenter. The students were more motivated, and they enjoyed in reading class. They also had a great enthusiasm toward the lesson, paid full attention to the materials, and got more fluent in comprehending texts.

In conducting the Classroom Action Research (CAR), the researcher encouraged the students to enjoy the activities during the lesson. Finally, the implementation of video through SQ3R method in English class can improve students' ability in reading narative text and their attitude toward learning English of the tenth grade students of one of MA in Sragen.

The results imply that video and SQ3R method are suitable teaching techniques to improve the students' competence in reading narative text. It means that the use of video and SQ3R method can be used in process of teaching reading. The use of video in teaching reading can help the students understand the story by giving them visualization about the content of the text. When the students read the text, it is possible that they find some difficult words. Video helps them at its scene on the video, the students can understand the meaning of those confusing words by guessing.

In the presentation, the students discuss with one another to comprehend the reading text. The students share their ideas and the audience give response toward the material. It is effective to improve the students' ability. If the students are able to comprehend the text well, it means that their reading comprehension is good.

The use of video in teaching reading can also engage the students' attention toward the lesson. They were more interested, enthusiastic, and active during the teaching learning process. The use of 
video also improves the students' interest toward the lesson. In addition, by implementing (Survey, Question, Read, Recite, Review) SQ3R method, most of the students become more active in the lesson. It implies that SQ3R method helped the students to comprehend narrative text.

Based on the conclusion above, the writer gives some suggestions for the teaching learning process in one of MA in Sragen, especially for English teacher, students, institution, and other researcher. First, the English teachers should improve their creativity in teaching reading, for example by using media to attract the students' motivation in order to make the students enjoy teaching learning process. The teacher should do some effort to make the class conducive so that it leads to the effectiveness for the teaching and learning process. Second, the students should be more active and confident during teaching learning process. They can implement SQ3R method as the way to learn and enjoy the study by watching video. Third, there should be the best effort from the school to facilitate the students in learning language. The school should provide means and infrastructure to make the teaching and learning success. The school also has to support the English teachers to improve their quality in teaching. Fourth, this article can be a reference for other researcher to conduct the next research. Other researchers are expected to use the finding of this research as a foothold to conduct the next research on similar problems. The researcher expects that the teacher and teacher candidates are able to conduct classroom action research by their own, so that there will be many techniques and strategies applied in teaching.

\section{BIBLIOGRAPHY}

Aebersold, Jo ann and Field, Marry LEF. (1997). From Reader to Reading Teacher. Cambridge: Cambridge University Press.

Burns, Anne. (1999). Collaborative Action Research for English Language Teachers. Cambridge: Cambridge University Press.

Harmer, Jeremy. (1998). How to Teach English: An Introduction to the Practice of English Language Teaching. England: Longman.

Mulyasa E. 2009. Praktik Penelitian Tindakan Kelas. Bandung: PT Remaja Rosdakarya.

Pang, Elizabeth S., Muaka, Angaluki., Bernbardt, Elizabeth., \& Kamil, Michael (2003). Teaching Reading. Geneva: IBE Publication Unit.

Robinson, F.P. (1946). Effective Study. New York: Harper \& Row.

Smaldino, SE, et al. (2005). Instructional Technology and Media for Learning. New Jersey: Pearson.

Stempleski, Susan and Barry Tomalin. 1990. Video in Action. New York: Prentice Hall University Press 